\title{
NASIONALISME DALAM PERSPEKTIF ALQURAN DAN HADITS
}

\author{
Mufaizin \\ Dosen PAI STAI Darul Hikmah Bangkalan \\ mufaizin@darul-hikmah.com
}

\begin{abstract}
Abstrak
Tanah air adalah sebutan bagi tempat kelahiran seorang seperti orang yang dilahirkan di indonesia maka indonesia akan menjadikan tanah airnya. cinta tanah air adalah suatu perasaan yang dimiliki setiap manusia atas tanah kelahirannya. Nasionalisme atau cinta tanah air merupakan perasaan bangga dan ikut memiliki sebuah wilayah tertentu.. Rasa kecintaan inilah yang nantinya akan membuat seorang warga negara rela berkorban, menjaga dan berjuang demi memajukan bangsanya. Itulah mengapa nasionalisme penting. Cinta tanah air memiliki hubungan yang harmonis dengan agama dan keimanan, sebagaimana ungkapan "Hubbul Wathan Minal Iman" cinta tanah air adalah sebagian dari iman. Nasionalisme tidak bertentangan dengan prinsip-prinsip agama. Hal ini bukan hanya tertera dalam beberapa ayat didalam Alquran akan tetapi juga tertuang dalam hadist nabi Muhammad SAW. Dalam potret Sirah nabawiyah dikisahkan bahwa pernah suatu ketika beliau sangat merindukan Makkah sehingga turun sebuah ayat yang berkaitan dengan perihal tersebut, yang selanjutnya ditafsirkan oleh sebagian ulama bahwa ayat tersebut memberikan isyarat bahwa cinta tanah air adalah sebagian dari iman.
\end{abstract}

\section{Kata kunci: Nasionalisme, Alquran, Hadits}

\section{A. Pendahuluan}

Wawasan kebangsaan bagi rakyat indonesia, utamanya umat islam, memiliki peran penting yang sangat strategis dalam menjaga ketahanan bangsa dalam kerangka Negara Kesatuan Republik Indonesia Nasionalisme adalah kesadaran keanggotaan dalam suatu bangsa yang secara potensial atau aktual bersama-sama berusaha mencapai mempertahankan, dan mengabdikan identitas, integritas, kemakmuran dan kekuatan sebuah bangsa atau dibahasakan dengan semangat kebangsaan.

Sebagai paham atau ajaran yang datang dari barat. Nasionalisme dimaknai beragam oleh berbagai golongan ditanah air, konsep cinta tanah air yang sejatinya berada pada tataran ruh jasmaniyah setiap insan, harus diterjemahkan kedalam berbagai pemikiran. 
Islam dan Negara adalah dua hal yang tak bisa dipisahkan. Pemaknaan masyarakat mengenai konsep Negara dan agama terus menjadi persoalan yang massif dikalangan akademisi, ulama'dan pemimpin Negara ${ }^{1}$

Polemik tentang nasionalisme sudah diperbincangkan dalam gagasan panIslamisme. Sebagian reformer muslim menganalisa, bahwa penyebab kemunduran kaum muslimin bukan karena kelemahan atau kekurangan internal kaum muslimin, melainkan adanya imperialisme agresif yang dilancarkan oleh Kristen Eropa untuk menghancurkan Islam.

Sebagian pemikir politik muslim menggagas bahwa nasionalisme yang murni adalah nasionalisme yang berwatak Eropa modern dan sekuler. Mereka yakin bahwa hanya nasionalisme model Eropa yang dapat dijadikan energi untuk melakukan perubahan sosial dan politik di dunia Islam. Sebaliknya, hal tersebut dibantah oleh yang lain, bahwa paham nasionalisme dengan berbasis material "negara-bangsa" yang hanya berpatok pada kriteria etnisitas, kultur, bahasa dan wilayah, akan mengabaikan agama sebagai sebuah ikatan sosial. Penafian agama dalam perumusan nasionalisme macam ini yang menimbulkan kritik pedas dari kalangan aktivis Islam. Mereka percaya, inilah yang menyebabkan lemahnya dunia Islam dalam menggalang kesatuan di antara mereka. Bahkan ada yang beranggapan bahwa Islam tidak kompatibel dengan nasionalisme, karena keduanya saling berlawanan secara ideologis. Kriteria nasional sebagai basis bangunan komunitas ditolak Islam. Basis-basis ini hanya bersifat nasional-lokal, sedangkan Islam mempunyai tujuan kesatuan universal. Kemudian spirit nasionalisme berupa sekularisme yang menghendaki pemisahan tegas antara agama dan politik bertentangan dengan prinsip-prinsip Islam.

Namun ada sebagian pemikir muslim yang bersikap netral, mereka tidak mau menerima begitu saja paham nasionalisme sekuler ala Barat, dan juga tidak serta merta menolak konsep nasionalisme secara keseluruhan. Kelompok ini memiliki pandangan yang berbeda. Bagi mereka, nasionalisme sejati, yakni suatu paham yang

\footnotetext{
${ }^{1}$ Said Agil Siradj, Nasionalisme Islam Nusantara, Jakarta: Pustaka Cinganjur 2015, Hlm 6.
} 
memperhatikan kepentingan seluruh warga bangsa tanpa kecuali, adalah bagian integral dari konsep "Pemerintahan Madinah" yang dibangun oleh Nabi Muhammad Saw bersama para sahabatnya. Dengan kata lain, paham nasionalisme yang dipahami demikian tidak bertentangan dengan Islam, justru menjadi bagian yang tak terpisahkan dalam konsep ajaran Islam secara keseluruhan. ${ }^{2}$

Islam sebagai agama yang Rahmatan lil 'alamin telah mengatur segala sesuatu yang berkaitan dengan kehidupan manusia. Sebagai agama yang sempurna, islam telah memberikan intisari dari nasionalisme. Intisari dari nasionalisme adalah rasa kecintaan terhadap tanah air. Konsep mengenai nasionalisme banyak tertuang dalam sumber pokok ajaran islam baik itu ayat-ayat Al-Qur'an maupun Hadits Nabi SAW. Al-Quran dan hadist sebagai sumber primer ajaran islam dan otoritatif secara eksplisit mungkin tidak menyebutkan mengenai pentingnya nasionalisme akan tetapi secara implisit para ulama melalui interpretasinya terhadap beberapa ayat dan hadist mengatakan bahwa nasionalisme di anjurkan oleh islam, Bertolak dari uraian diatas penulis akan mengupas dan mengkaji tentang Nasionalisme dalam perspektif AlQur'an dan Hadits. Sebagai respon penolakan dan upaya untuk menepis anggapan sementara orang dari sebagian kelompok umat islam yang berasumsi bahwa Nasionalisme tidak ada dalilnya, atau tidak ada landasannya dalam islam.

\section{B. Pembahasan}

\section{Nasionalisme dalam Islam}

Dalam perkembangan peradaban manusia, interaksi sesama manusia berubah menjadi bentuk yang lebih kompleks dan rumit. Dimulai dari tumbuhnya kesadaran untuk untuk menentukan nasib sendiri di kalangan bangsa-bangsa yang tertindas kolonialisme dunia, termasuk Indonesia, hingga melahirkan semangat untuk mandiri dan bebas menentukan masa depanya sendiri.

\footnotetext{
${ }^{2}$ Mugiyono, Relasi Nasionalisme Dan Islam Serta Pengaruhnya Terhadap Kebangkitan Dunia Islam Global, 2014, Jurnal Ilmu Agama Islam Uin Raden Fatah Palembang.
} 
Dalam situasi perjuangan merebut kemerdekaan, dibutuhkan suatu konsep sebagai pembenaran rasional dari tuntutan terhadap penentuan nasib sendiri yang dapat mengikat keikutsertaan semua orang atas nama sebuah bangsa. Atas dasar pembenaran tersebut, selanjutnya mengkristal dalam konsep paham ideologi kebangsaan yang disebut dengan nasionalisme. ${ }^{3}$

Nasionalisme berasal dari kata nation yang dipadankan dengan bangsa.bangsa mempunyai dua pengertian, yaitu pengertian antropologis serta sosiologis, dan dalam pengertian politis. Dalam pengertian antropologis dan sosiologis, bangsa adalah suatu masyarakat yang merupakan suatu persekutuan hidup yang berdiri sendiri dan masing-masing anggota persekutuan hidup tersebut merasa satu kesatuan ras, bahasa, agama, sejarah, dan adat istiadat. ${ }^{4}$ Sedangkan yang dimaksud bangsa dalam pengertian politik adalah masyarakat dalam suatu daerah yang sama, dan mereka tunduk pada kedaulatan negaranya segabai suatu kekuasaan tertinggi. ${ }^{5}$

Rupert Emerson mendefinisikan nasionalisme sebagai komunitas orang-orang yang merasa bahwa mereka bersatu atas dasar elemen-elemen signifikan yang mendalam dari warisan bersama dan bahwa mereka memiliki takdir bersama menuju masa depan. Sedangkan menurut Ernest Renan, nasionalisme merupakan unsur yang dominan dalam kehidupan sisoal-politik sekelompok manusia dan telah mendorong terbentuknya suatu bangsa guna menyatukan kehendak untuk bersatu. Anggapan ini paralel dengan pandangan islam sebagaiman termaktub dalam Alquran surah AlHujurat, 49:13. ${ }^{6}$

Lebih lanjut dikalangan umat Islam dikenal sebuah pepatah yang berbunyi: hubbul wathani minal iman (cinta tanah air adalah bagian dari iman) yang dipopulerkan oleh pendiri organisasi Nahdlatul ulama KH hasyim Asyari pada 22 oktober tahun 1945

3 Dede Rosyada Dkk, Pendidikan Kewargaan, Demokrasi, Hak Asasi Manusia Dan Masyarakat Madani, (Jakarta: Icce Uin Syarif Hidayatullah, 2003), Hlm. 24.

${ }^{4}$ Badri Yatim, Soekarno, Islam Dan Nasionalisme, Jakarta: Logos Wacana Ilmu, 1999, Hlm. 57-58.

${ }^{5}$ Badri Yatim, Op Cit, Hlm. 67.

${ }^{6}$ Anhiyaksa Dault, Islam Dan Nasionalisme, Jakarta:Yadaulu.2003 Hlm. 2. 
(yang ditetapkan sebagai hari santri oleh presiden Jokowi) menyerukan kewajiban bagi setiap Umat islam untuk berjuang membela negara dan bangsa Indonesia dalam menghadapi penjajahan Belanda dan Jepang yang selanjutnya seruan tersebut dikenal dengan Resolusi jihad.

Mengaitkan Islam dengan kebangsaan dapat dijelaskan dalam dua perspektif. Pertama, dari prespektif pluralisme dalam persatuan, Islam dan nasionalisme mempunyai hubungan positif. Islam mempunyai pengalaman panjang dan bahkan pioneer terbentuknya nasionalisme yang melahirkan negara bangsa. Negara madinah yang didirikan Nabi Muhammad adalah negara bangsa pertama di dunia. Kedua, dari perspektif uneversalisme, menurut Mansur, kebangsaan bertentangan dengan Islam. Sebagai agama universal, Islam tidak membatasi peruntukan bagi wilayah geografis dan etnis tertentu. Namun demikian, Islam tidak menafikan kenyataan bahwa setiap orang mempunyai afiliasi terhadap tanah air tertentu. Maka pepatah yang mengatakan "cinta tanah air sebagian dari iman", seperti dikataakan sebelumnya, sangat mempengaruhi pandangan kaum muslimin pada umumnya. Maka benarkah Mansur bahwa memang Islam tidak bertanah air, tetapi kaum musliminnya bertanah air. Dan umat Islam berkewajiban menjaga, mencintai, dan membela tanah airnya. ${ }^{7}$

Realitas kebangsaan dalam tubuh umat Islam merupakan implementasi dari misi "rahmatan lil alamin" sehingga eksklusifitas mereka harus diminimalkan. Sikap kebangsaan bagi mereka juga cermin dari faham monotheis yang menjadi fundamental keyakinannya, dimana semua realitas itu- termasuk eksklusifitas dan individualitas- haruslah dinegasikan dan hanya Allah yang menjadi esensi sesungguhnya, "la ilaha illallah". Norma tersebut kemudian diaplikasikan oleh Rasulullah SAW. Dalam membangun masyarakat Madinah di bawah panji "Piagam Madinah". Dalam perjanjian luhur yang mengikat Yahudi, Kristen, Muslim dan Paganis tersebut kata Islam dan Alquran sama sekali tidak pernah ditampilkan. Karakter ini diperkuat dengan risalah terakhir dalam Islam yang disampaikan Nabi

\footnotetext{
${ }^{7}$ Dwi Purwoko Dkk. Negara Islam, Percikan Pemikiran: H. Agus Salim, Kh. Mas Manshur, Mohammad Natsir, Kh. Hasyim Asyari, Depok: Permata Atika Kreasi. 2001 Hlm.37-38.
} 
saw. Dalam Haji Wada'. Dalam satu-satunya ibadah haji yang pernah dilakukan Rasulullah semasa hidup tersebut, beliau berpesan kepada seluruh umat manusia untuk selalu menghormati kehormatan dan hak-hak seseorang, mengangkat kehormatan wanita, menghindarkan pertumpahan darah dan seterusnya. ${ }^{8}$

Semangat nasionalisme merupakan semangat kelompok manusia yang hendak membangun suatu bangsa yang mandiri, dilandasi satu jiwa dan kesetiakawanan yang besar, mempunyai kehendak untuk bersatu dan terus menerus ditingkatkan untuk bersatu, dan menciptakan keadilan dan kebersamaan. Nasionalisme ini, misalnya membentuk persepsi dan konsepsi identitas sosial kaum pergerakan Indonesia sebagai suatu kekuatan politik yang tidak bisa dinegasikan oleh penguasa kolonial. Tjuan nasionalisme ini adalah pembebasan dari penjajahan dan menciptakan masyarakat/negara yang adil, dimana tidak ada lagi penindasan manusia oleh manusia.

Nasionalisme harus terpatri dalam sanubari setiap anak bangsa demi menjaga semangat mempertahankan, siap berkorban, dan berjuang demi bangsa sehingga tetap lestari dan kemajemukannya baik di bidang agama, suku, dan budaya dapat terpelihara menjadi kekuatan ril yang memperkokoh kedaulatannya, dengan demikian tercipta suasana kehidupan yang damai saling menghormati menghargai melindungi dan mengasihi ${ }^{9}$.

Selanjutnya unsur cinta tanah air (patriotisme) merupakan pembuktian rasa kebangsaan. Sudah menjadi tabiat manusia, mencintai negeri tempat ia dilahirkan. Bahkan kemanapu ia pergi, rasa ingin kembali ke tanah air senantiasa muncul. ${ }^{10}$

\footnotetext{
${ }^{8}$ Said Aqiel Siradj. Fikih Kebangsaan, Fiqih Demokratik Kaum Santri, Jakarta: Pustaka Cinganjur.1999 Hlm. 193.

9 Tim Bahtsul Masa'il Himasal, Fikih Kebangsaan Merajut Kebersamaan Di Tengah Kebhinekaan, Lirboyo Pres, 2018, Hlm 14.

${ }^{10}$ M. Natsir, Agama Dan Negara Dalam Perspektif Islam, Jakarta: Media Da'wah, 2001, Hlm. 46.
} 


\section{Nasionalisme dalam perspektif Al-Quran}

Ada yang menyebut bahwa nasionalisme itu tidak ada landasan atau dalilnya di dalam Islam. Secara sederhana bisa kita samakan antara nasionalisme dan cinta tanah air. Jika nasionalisme itu adalah cinta tanah air, maka sesungguhnya dalilnya di dalam alQuran begitu banyak. Diantaranya adalah firman allah SWT:

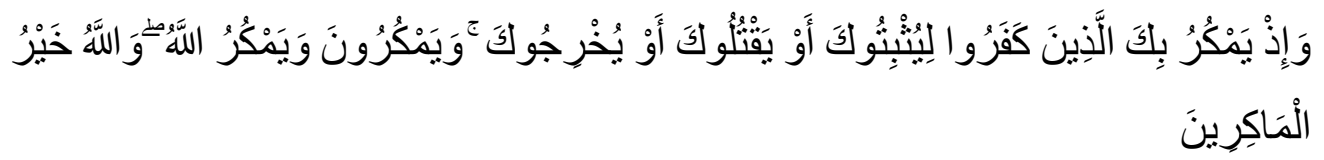

"Dan (ingatlah) ketika orang-orang kafir (Quraisy) memikirkan daya upaya terhadapmu untuk menangkap dan memenjarakanmu atau membunuhmu, atau mengusirmu. Mereka memikirkan tipu daya dan Allah menggagalkan tipu daya itu. Dan Allah sebaik-baik Pembalas tipu daya. (Qs. al-Anfal 30)"

Al-Quran menggambarkan tanah air adalah suatu hal yang sangat berharga. Al-Quran menganggap mengusir seseorang dari tanah air sepadan dengan membunuh nyawanya, dalam ayat lain disebutkan:

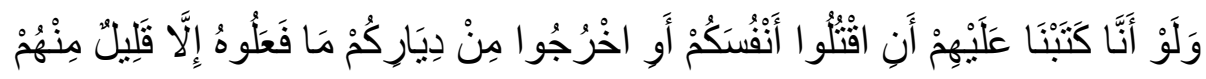

"Dan sekalipun telah Kami perintahkan kepada mereka, "Bunuhlah dirimu atau keluarlah kamu dari kampung halamanmu," ternyata mereka tidak akan melakukannya, kecuali sebagian kecil dari mereka (an-nisa:66)”

Imam Fakhruddin ar-razi mengungkapkan hal ini ketika menafsiri ayat di atas:

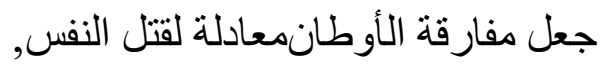

"Allah menjadikan berpisah dengan tanah air sebanding dengan dibunuhnya nyawa”. 11

Bahkan Mula Ali Al-Qari seorang pakar hadis menafsiri fitnah dalam ayat:

\footnotetext{
${ }^{11}$ Fakhruddin Ar-Razi, Mafatihul-Ghaib Al Musamma Bi Tafsir Al Kabir, MaktabahSyamilah Jilid X, Hlm, 133
} 


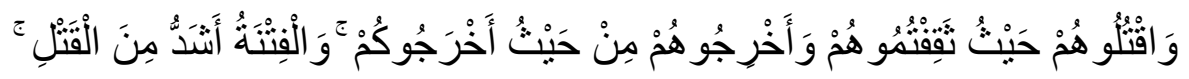

"Dan bunuhlah mereka di mana kamu temui mereka, dan usirlah mereka dari mana mereka telah mengusir kamu. Dan fitnah itu lebih kejam daripada pembunuhan”.

Dengan terusir dari tanah air.sehingga dengan penafsiran ini terusir dari tanah air lebih berat dan kejam dibanding pembunuhan.

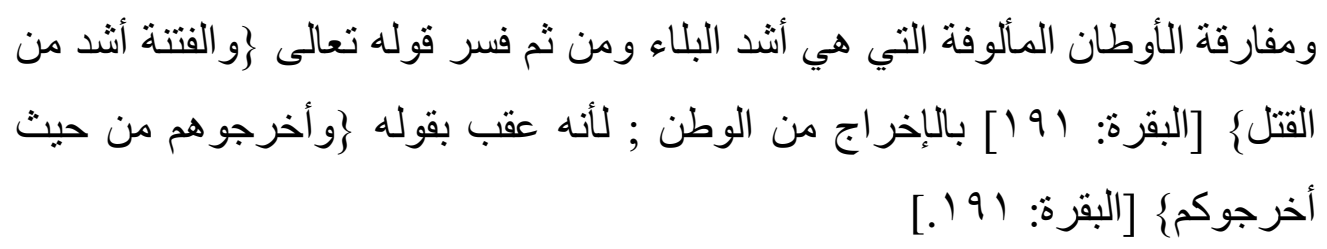

"Berpisah dengan tanah air yang dicintai adalah cobaan paling berat. maka dari itulah firman Allah "dan fitnah itu lebih berat dari pembunuhan" ditafsiri dengan diusir dari tanah air sebab terusan dari ayat itu adalah "maka usirlah mereka sebagaimana mereka mengusir kalian"'(Al-Baqarah:191)",12

Ayat-ayat beserta penafsiran diatas menunjukkan betapa sangat berharga nya sebuah tanah air, dalam pandangan Alquran sampai-sampai pengusiran dari tanah air disandingkan dengan pembunuhan atas nyawa atau bahkan lebih berat dan kejam.

Oleh karenanya ketika menyebutkan kewajiban suci jihad, al-quran seringkali menghubungkan dan menyandingkannya dengan membela tanah air dari cengkraman penjajah. Hari ini ditemukan dalam banyak tempat dalam firman Allah SWT:

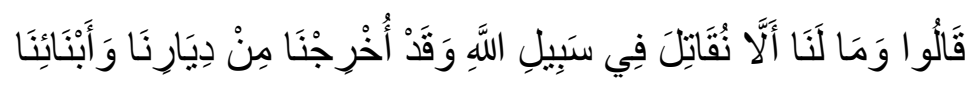

"Mereka menjawab, "Mengapa kami tidak akan berperang di jalan Allah, sedangkan kami telah diusir dari kampung halaman kami dan (dipisahkan dari) anak-anak kami?".(Al-Baqarah:246)”

\footnotetext{
${ }^{12}$ Mula Al-Qari, Mirqatul Mafatih Syarah Misykat-Al-Mashabih, Beirut: Darul-Fikr, 2002, Jilid Vi Hlm 2630
}

Mufaizin, M.Pd,I 


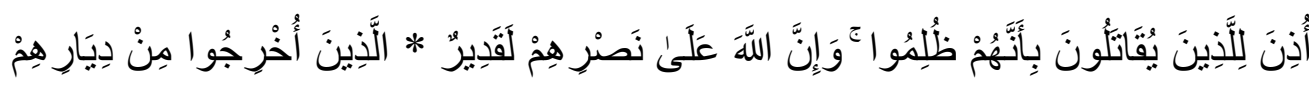

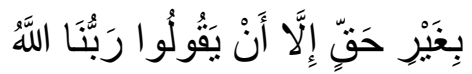

'Telah diizinkan berperang bagi orang-orang yang diperangi, karena sungguh mereka telah dianiaya. Sungguh Allah benar-benar maha kuasa untuk menolong mereka. Ialah orang-orang yang telah diusir dari kampung halaman mereka tanpa alasan yang benar kecuali Sebab mereka berkata Tuhan kami hanya Allah". (Alhajj:39-40)"

Dengan demikian, jihad membela tanah air seperti yang diserukan ayat di atas tidak lain adalah ruh semangat patriotisme dan nasionalisme untuk membela tanah air.

pada firman Allah SWT yang lain terdapat isyarat bahwa mencintai tanah air adalah sebagian dari iman:

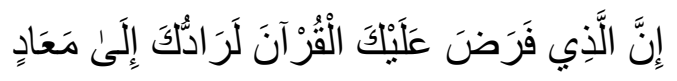

"sungguh hebat yang mewajibkan atasmu melaksanakan hukum-hukum Alquran benar-benar akan mengembalikan muka tempat kembali (kota Makkah)"(Alashas:85)

Ayat di atas turun saat nabi dalam perjalanan malam menuju Madinah. Sesampainya di daerah juhfah, nabi merasakan kerinduan yang teramat mendalam pada tanah Mekah. Lalu Jibril turun dan menyampaikan ayat ini. Dalam karya tafsirnya Ruhulbayan, Ulama berkebangsaan turki bermadzhab hanafi, yakni Syekh Ismail Haqqi bin Musthofa Al istanbuli Al Hanafi memaparkan bahwa dalam ayat diatas terdapat isyarat bahwa cinta tanah air adalah sebagian dari iman beliau menuturkan bahwa Dalam ayat di atas terdapat isyarat bahwa cinta tanah air adalah sebagian dari iman. ${ }^{13}$ Ada juga ayat lain yang menyamakan level keterusiran seseorang dari negaranya dengan pembunuhan:

\footnotetext{
${ }^{13}$ Ismail Haqqi Al Istanbuli Al Hanafi, Tafsir Ruhul-Bayan, Beirut: Darul-Fikr Tt. Jilid Vi Hlm, 440
} 


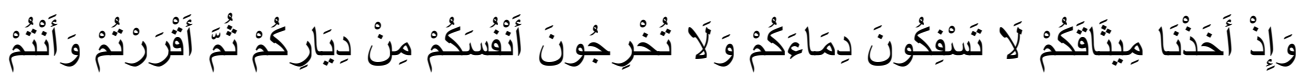 نَثَنْهَدُونَنَ}

"Dan (ingatlah), ketika Kami mengambil janji dari kamu (yaitu): kamu tidak akan menumpahkan darahmu (membunuh orang), dan kamu tidak akan mengusir dirimu (saudaramu sebangsa) dari kampung halamanтu, kemudian kaти berikrar (akan memenuhinya) sedang kamu mempersaksikannya. (Qs. al-Baqarah 84")

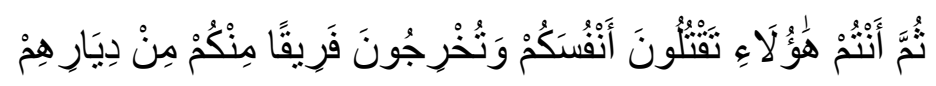

"Kemudian kamu (Bani Israil) membunuh dirimu (saudaramu sebangsa) dan mengusir segolongan daripada kamu dari kampung halamannya (Qs. al-Baqarah $85)$ "

Semua ayat yang menyamakan level antara terbunuh dan terusir dari negara itu adalah ayat yang menegaskan tentang begitu pentingnya kedudukan tanah air dan negara dalam beragama.

Dalam sebuah ayat Syaikh Ibnu Asyur dalam Tafsirnya Al-Tahrir wa al-Tanwir menyatakan bahwa kaum muslimin disyariatkan untuk berdoa atas tanah-airnya. ${ }^{14}$ walaupun sebetulnya secara harfiah ayat tersebut hanyalah sebuah doa dari Nabi Ibrahim as. untuk kota Mekkah.

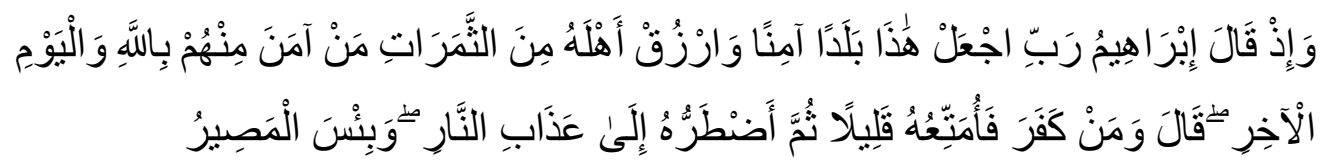

"Dan (ingatlah), ketika Ibrahim berdoa, "Ya Tuhanku, jadikanlah negeri ini, negeri yang aman sentosa, dan berikanlah rezeki dari buah-buahan kepada penduduknya yang beriman diantara mereka kepada Allah dan hari kemudian. Allah berfirman: "Dan kepada orang yang kafir pun Aku beri kesenangan sementara, kemudian Aku

\footnotetext{
${ }^{14}$ Muhammad Thohir Bin Asyur At-Thunisy, At-Tahrir Wa-At-Tanwir, Maktabah-Syamilah, Jilid I Hlm 714
} 
paksa ia menjalani siksa neraka dan itulah seburuk-buruk tempat kembali.” (Qs. alBaqarah 126)"

Lebih lanjut Ibnu Asyur mengatakan bahwa doa ini juga diucapkan oleh seluruh nabi atas negaranya masing-masing. Setiap nabi berdoa atas negaranya agar terwujud keadilan, kebanggan, dan kesejahteraan. Itu artinya semua nabi memiliki rasa nasionalisme terhadap bangsa dan tanah airnya. Oleh karena itu Menurut ulama asal Tunisia ini, ketiga hal ini (keadilan, kebanggaan dan kesejahteraan) penting untuk membangun negara dan mengatur kekayaan dan sumber daya tiap negara. ${ }^{15}$

\section{Nasionalisme dalam Perspektif Hadist}

Dalam beberapa hadits dan sirah Nabawiyah di sebutkan bahwa Rasulullah SAW, sangat mencintai kota Mekah sebagai tanah airnya, karena ia dilahirkan di Mekah, diasuh oleh orang Mekah, menghabiskan masa kecil di makkah, ayah bundanya asli penduduk Mekah, dan semua sanak familinya tinggal di Mekah.

akan tetapi setelah beliau ditugaskan untuk berdakwah ke jalan Allah dengan menyebarkan agama Islam di Mekah maka penduduk Mekah menjadi bringas dan tak segan-segan mau membunuh dan mengusirnya, sehingga akhirnya beliau hijrah ke Madinah.

Dari situlah Madinah juga mengisi ruang hati nabi Muhammad SAW, karena kota Madinah dan penduduknya menerima nabi dan dakwahnya hingga keluar ungkapan tentang doa dan kecintaan nabi kepada tanah airnya:

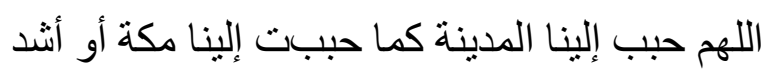

"Ya Allah jadikan kami mencintai Madinah sebagaimana kami mencintai Mekah bahkan lebih darinya". ${ }^{16}$

\footnotetext{
${ }^{15}$ Muhammad Thohir Bin Asyur At-Thunisy, Op Cit, Hlm 715

${ }^{16}$ An Nasa'i, As Sunanul-Kubro, Maktabah-Syamilah, Jilid Ii Hlm 484
} 
Para ahli hadis dan sejarah menggambarkan nabi adalah sosok yang sangat mencintai tanah airnya, sebagaimana yang diungkapkan oleh imam Ad-zahabi salah satu ahli sejarah dan sirah nabi itu menyebutkan beberapa sifat nabi. dalam melukiskan sosok nabi beliau menyampaikan:

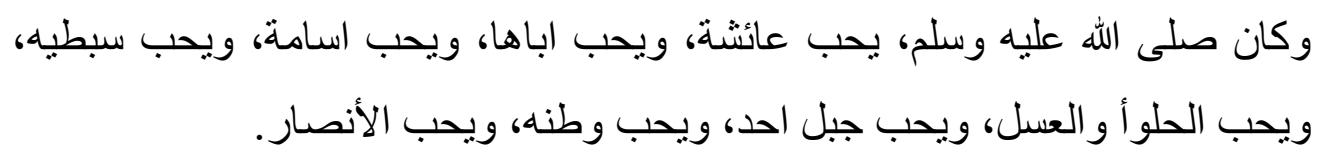

"Rasulullah adalah sosok yang mencintai Aisyah mencintai ayah Aisyah mencintai Usamah mencintai kedua ujungnya menyukai manis manis dan madu mencintaimu mencintai tanah airnya dan mencintai para sahabat anshor. " 17

Dari kecintaan nabi yang teramat mendalam terhadap tanah airnya ini para ulama akhirnya merumuskan bahwa disyariatkan mencintai tanah air bagi umat Islam seperti komentar para ulama atas hadis shahih riwayat imam Bukhari berikut ini:

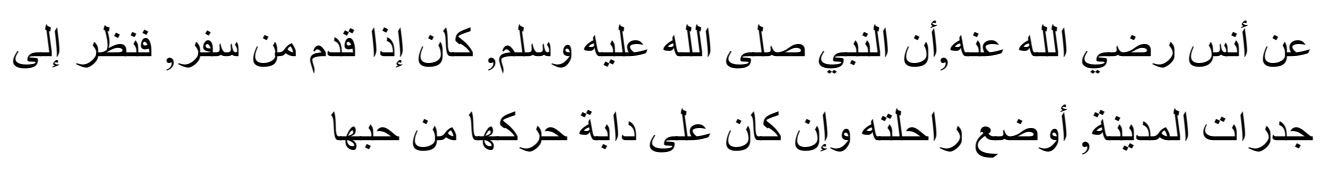

"Sungguh ketika nabi pulang dari bepergian beliau melihat tembok-tembok kota Madinah beliau mempercepat laju untanya dan ketika mengendarai tunggangan beliau menggerak-gerakkan tunggangannya semua ini beliau lakukan karena kecintaannya terhadap kota Madinah.",18

Al-hafidz Ibnu Hajar salah satu ulama pakar hadits kenamaan menjelaskan bahwa hadits diatas menunjukkan keutamaan kota Madinah dan disyariatkannya mencintai tanah air;

$$
\text { وفي الحديث دلالة على فضل المدينة و على مشرو عية حبالوطن }
$$

${ }^{17}$ Al Dzahabi, Siyar-A'lami-Nubala', Maktabah-Syamilah, Jilid Xv. Hlm 394

${ }^{18}$ Al Bukhori, Shohih-Bukhori, Maktabah-Syamilah, Jilid I. Hlm 620 
"Dalam hadis itu terdapat petunjuk atas keutamaan kota Madinah dan disyariatkannya mencintai tanah air serta merindukannya". 19

Dalam riwayat lain terdapat suatu slogan yang sangat populer:

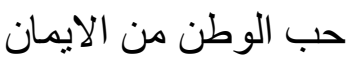

"Cinta tanah air adalah sebagian dari iman".

Meski banyak pakar hadist menilai bahwa ungkapan tersebut tergolong Maudlu' namun sebagaimana disampaikan oleh Imam As-Sakhowi substansi dan makna hadits tersebut adalah Shohih dan benar sebab adanya banyak hadits lain yang menyebutkan bahwa Rasulullah begitu mencintai tanah airnya. ${ }^{20}$

Sementara pakar hadis lain Ismail bin Muhammad Al-Ajluni berpendapat bahwa cinta tanah air dalam hadits di atas merupakan sebagian dari iman selama sebabnya adalah melakukan kebaikan kebaikan untuk tanah air seperti menyambung persaudaraan berbuat baik kepada penduduk tanah airnya dan mengasihi fakir miskin dan anak yatim..$^{21}$

Cinta tanah air menjadi sebagian dari iman apabila didasari dan diekspresikan dengan sikap patriotisme dan berbuat kebaikan sesuai dengan bidangnya masingmasing demi kemakmuran dan kesejahteraan bangsa dan tanah airnya, Imam Ibnu Allan Muhammad bin Ali as shodiqi berkata:

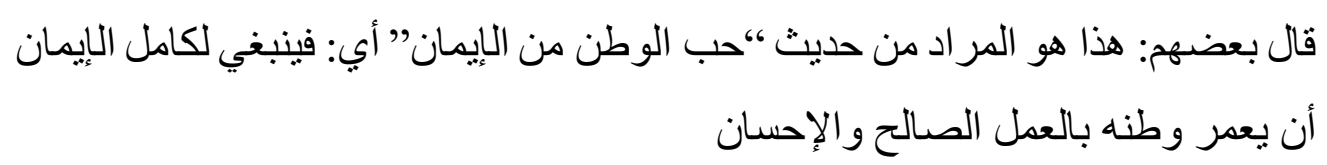

\footnotetext{
${ }^{19}$ Al Asqalani, Fathul-Bari, Maktabah-Syamilah, Jilid Iii. Hlm 621, Lihat Juga Badruddin Al Aini, Al Umdah Al Qari Syarah Shohih Bukhori, Jilid X. Hlm 135

${ }^{20}$ As Sakhowi, Al Maqasidul-Hasanah, Maktabah-Syamilah, Jilid I, Hlm 297

${ }^{21}$ Al Ajluni, Kasyful-Khafa', Maktabah-Syamilah, Jilid I, Hlm 297.
} 
"Inilah yang di maksud dari hadits cinta tanah air adalah sebagian dari iman yaitu hanya bagi orang yang sempurna imannya untuk meramaikan negaranya dengan amal soleh dan kebaikan"22

Dalam penerapannya, semangat nasionalisme mampu menciptakan dialog kehidupan yang rukun dan damai. Bahkan di masa sekarang sangat diperlukan untuk memperkuat sendi-sendi kenegaraan dari berbagai paham seperti radikalisme, ekstremisme, dan semacamnya, yang merongrong kebhinnekaan bangsa ini. Oleh karena itu Islam memandang Nasionalisme adalah media untuk memakmurkan negara sebagaimana juga diungkapkan oleh sayyidina Umar:

$$
\text { لو لا حب الوطن لحرب بلد السؤ فبحب الاوطان عمرت البلدان }
$$

"Seandainya Tidak Ada Cinta Tanah Air Niscaya Akan Semakin Hancur Lebur negara yang Terpuruk, Maka Dengan Cinta Tanah Air Negeri-Negeri Akan Termakmurkan."23

Sayyidina Ali pun juga mengungkapkan hal senada:

$$
\text { عمرت الدنيا بحب الاوطان }
$$

"Dunia termakmur kan dengan cinta tanah air"24.

Bahkan terdapat sebuah riwayat maqolah dari imam $\mathrm{Al}$ asmu'i yang berbunyi:

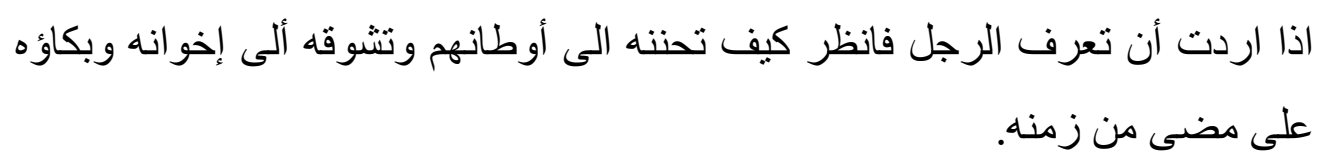

${ }^{22}$ Ibnu Allan. Dalilul-Falihin Syarah Riyadhussholihin, Maktabah-Syamilah Jilid I, Hlm 22

${ }^{23}$ Isma'il Haqqi, Op Cit, Jilid Vi, Hlm.442

${ }^{24}$ Al Halabi, Al A'laqul Khotiroh Fi Dzikri Umaro'-Syam-Wal Jazirah, Maktabah-Syamilah Jilid I, hlm 2 
"Jika kamu ingin mengenali seseorang maka perhatikan bagaimana kerinduannya pada tanah airnya, kerinduannya kepada kawan-kawannya dan tangisannya atas apa yang telah berlalu dari masa hidupnya." ${ }^{25}$

\section{Kesimpulan}

Dari beberapa ayat, hadist dan Atsar sahabat serta Pemaparan para Ulama' di atas maka dapat disimpulkan bahwa:

Nasionalisme ada dalil dan landasannya baik dalam Al-Quran maupun hadist, Ayatayat beserta penafsiran dan komentar para ulama diatas menunjukkan betapa sangat berharganya sebuah tanah air, dalam pandangan Alquran, sampai-sampai alquran menyandingkan pengusiran dari tanah air dengan pembunuhan atas nyawa atau bahkan lebih berat dan kejam. dalam hadistpun demikian nabi Muhammad SAW sangat mencintai Makkah sekalipun beliau terusir darinya, dan juga mencintai Madinah sebagai tempat tinggalnya, menyebarkan dakwah islam hingga beliau wafat dan dimakamkan disana.

Walhasil Nasionalime sama sekali tidak bertentangan dengan ajaran islam. Bahkan semua unsur yang melahirkan ajaran tersebut, inklusif dalam al-Quran, sehingga seorang muslim yang baik adalah anggota suatu bangsa yang baik pula. Menjadi seorang muslim bukanlah sebuah penghalang untuk memiliki identitas ganda. Identitas keislaman tidakklah menghalangi keanggotaannya sebagai bagian dari bangsa dan warga Negara atau sebaliknya. Nasionalisme tidak perlu dipertentangkan dengan Islam bahkan sebenarnya dapat menjadi media mengejawantahkan ajaranajarannya seperti melakukan amal shaleh dan kebaikan, menjalin silaturahmi dan menyantuni anak yatim dan fakir miskin.

${ }^{25}$ As Sakhowi, Op Cit, hlm.297 


\section{DAFTAR PUSTAKA}

Al-Aini, Badruddin, Al Umdah Al Qari Syarah Shohih Bukhori, Maktabah-Syamilah Jilid X.

Al-Asqalani, Ibnu Hajar, Fathul-Bari Syarah Shohih Bukhori, Maktabah-Syamilah, Jilid III.

Al-Bukhori, Abu abdillah, Shohih-Bukhori, Maktabah-Syamilah, Jilid I.

An-Nasa'i, As Sunanul-Kubro, Maktabah-Syamilah, Jilid II

Al-Dzahabi, syamsuddin abi abdilllah, Siyar-A'lami-Nubala', Maktabah-Syamilah, Jilid XV.

Al Ajluni,Ismail bin Muhammad, Kasyful-Khafa', Maktabah-Syamilah, Jilid I,

Al-Mula ali Al-Qari, Nurudin, Mirqatul Mafatih Syarah Misykat-Al-Mashabih, Maktabah-Syamilah Jilid VI

As-Sakhowi, Syamsyuddin, Al Maqasidul -Hasanah Fi-Bayanil-katsirMinalAhaditsil-Musytahiroh Ala-Al-sinah, Maktabah-Syamilah, Jilid I

Ar-Razi, Fakhruddin, Mafatihul-Ghaib Al-Musamma Bi Tafsir Al-Kabir, MaktabahSyamilah Jilid X

Al-Halabi, Abi Abdillah Muhammad bin ali, Al-A 'laqul Khotiroh Fi Dzikri Umaro'Syam-Wal Jazirah, Maktabah-Syamilah Jilid I,

Dwi Purwoko Dkk. Negara Islam, Percikan Pemikiran: H. Agus Salim, Kh. Mas Manshur, Mohammad Natsir, Kh. Hasyim Asyari, Depok: Permata Atika Kreasi. 2001.

Ibnu Asyur At-Thunisy, Muhammad Thohir, At-Tahrir Wa-At-Tanwir, MaktabahSyamilah, Jilid I

Ibnu-Allan, Muhammad bin Ali As Shodiqi,. Dalilul-Falihin Syarah RiyadhusSholihin, Maktabah-Syamilah Jilid I,

Ismail Haqqi Al Istanbuli Al-Hanafi, Tafsir Ruhul-Bayan, Beirut: Darul-Fikr Tt. Jilid Vi Hlm, 440

Mugiyono, Relasi Nasionalisme Dan Islam Serta Pengaruhnya Terhadap Kebangkitan Dunia Islam Global, 2014, Jurnal Ilmu Agama Islam UIN Raden Fatah Palembang. 
M. Natsir, Agama Dan Negara Dalam Perspektif Islam, Jakarta: Media Da'wah, 2001,

Rosyada, Dede, dkk. Pendidkan Kewargaan, Demokrasi, Hak Asasi Manusia dan Masyarakat Madani, Jakarta: ICCE UIN Syarif Hidayatullah. 2003

Said Aqiel Siradj. Islam Kebangsaan, Fiqih Demokratik Kaum Santri, Jakarta: Pustaka Cinganjur.1999

Tim Bahtsul Masa'il Himasal, Fikih Kebangsaan Merajut Kebersamaan Di Tengah Kebhinekaan, Lirboyo Pres, 2018.

Yatim, Badri. Soekarno, Islam dan Nasionalisme, Jakarta: Logos Wacana Ilmu. 1999 